\title{
Geothermal application on an artificial lake powered using photovoltaic energy
}

\author{
Gándara Villadóniga, V**, López Agüera A. *, Vázquez García, M*., Rodríguez Cabo I.* \\ * Sustentable Energetic Applications Group. Department of Particle Physics \& Galician Institute of High Energy \\ Physics. South Campus 15702 Santiago de Compostela (Spain) \\ .phone:+34 981 563100, fax:+34 981521091 ext.: 13974, email: a.lopez.aguera@usc.es
}

\begin{abstract}
. reproducibility.

\section{Introduction.}

In the following, we describe an intervention in a historically highly polluted zone legated to conventional energy production. In fact, the future artificial lake $* * *$, located on As Pontes de García Rodríguez (A Coruña), has born by water filling of the hole created by an opencast lignite mine.
\end{abstract}

This paper describes a geothermal low enthalpy installation mounted in an artificial lake created by recover of an ancient lignite mine. The associated heats bombs will be powered using photovoltaic solar energy with the aims of acclimatise a passive tertiary sector use. The main contribution of the proposed project is a pioneer multi-source renewable energy application with both high social visibility and

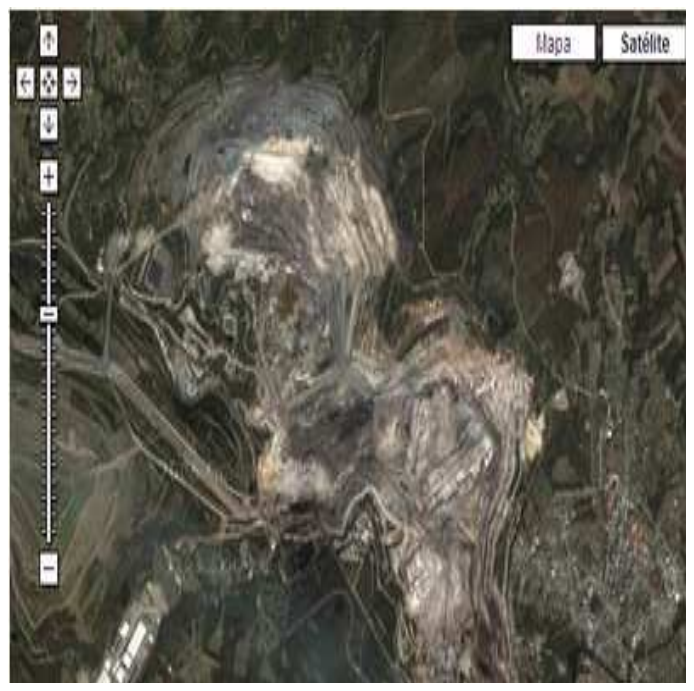

Figure 1: Google map of the situation.

We propose the use of the man-made lake as geothermal low enthalpy source optimized to provide acclimatisation to public services. Moreover, a solar photovoltaic system will be dimensioned to power the associated heat bomb.

The full installation will be included in a global rehab of the zone containing the creation of a man-made beach, a museum and a sport area.

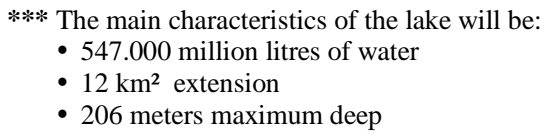

\section{Description.}

The project initially raises the installation of 18 200meters deep shafts in the central area of the lake with a heat utile capacity of 55MW per year to supply acclimatisation to $700 \mathrm{~m}^{2}$. The heat bombs consume, calculated in $500 \mathrm{KW}$, will be supplied by a photovoltaic installation located in one of the islands. This system has been over dimensioned to support a hypothetic streetlight during the summer period.
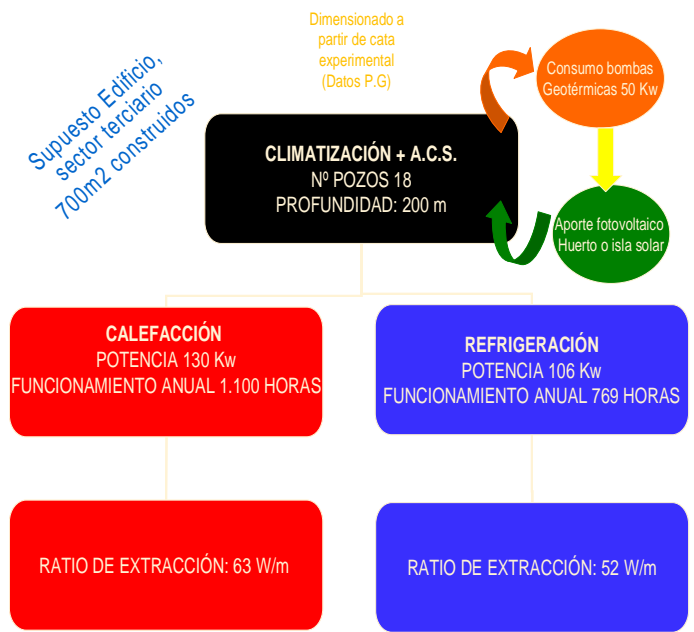

Figure $2:$ Esqueme of the proposed geothermal installation.

We estimate the climatization needs in potential values for heating of around $130 \mathrm{KW}$ and for cooling of $106 \mathrm{KW}$; the annual working time is 
1.100hours and 769 respectively. The thermic conductivity of the area, defined from experimental data obtained by experimental prospections in Santiago de Compostela, raises a media value of $2.2 \mathrm{~W}(\mathrm{mK})$, which means 18 tests drilling to cover the needs of the building. This offers an extraction ratio of $63 \mathrm{~W} / \mathrm{m}$ for heating and $52 \mathrm{~W} / \mathrm{m}$ for cooling.

To cover the demand of the geothermal bombs we consider the option to do an island or solar photovoltaic and enclosed garden with thermal support with a scheme similar to the figure:

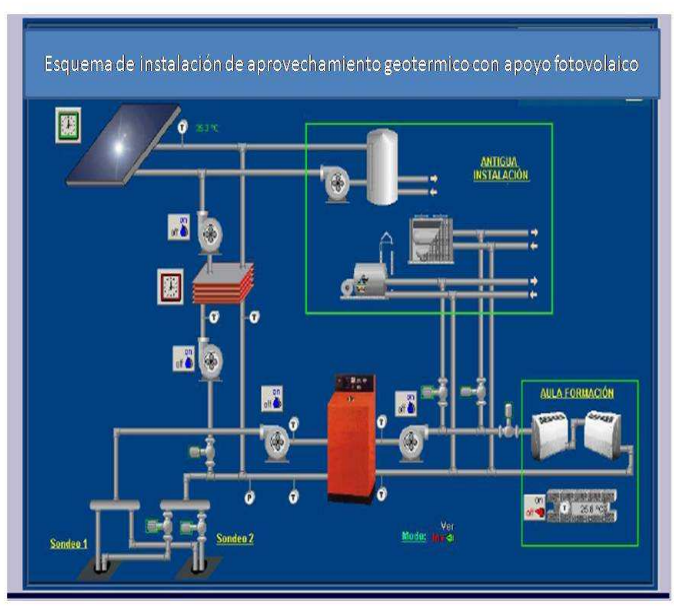

Figures 3: scheme of installation using thermal support.

The first thing that must do is a Test of Thermal Response (TRT) of the subsoil that is directed to determine the following parameters:

a) Stable temperature of the Subsoil (K)

b) Thermal Conductivity of the subsoil I object of study $\mathrm{W} / \mathrm{mK}$

c) Thermal Resistance of the well of exchange $\mathrm{mK} / \mathrm{W}$

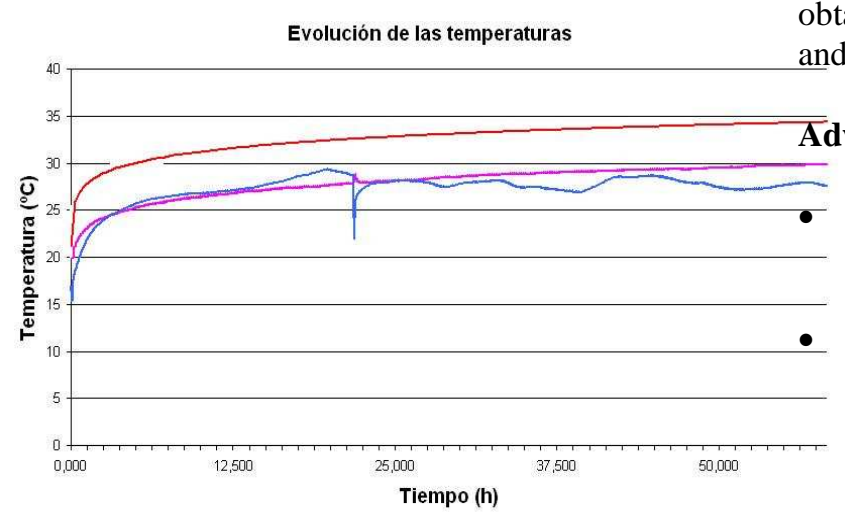

High efficiency because the COP is expected between 4 and 6 (compared with the 2 of the air-air heat bomb).

Important energy savings. Around 25\% of the total heating and $50 \%$ of the cooling needs. Figure 3 shows the expected saving with respect to the most common used combustibles. 


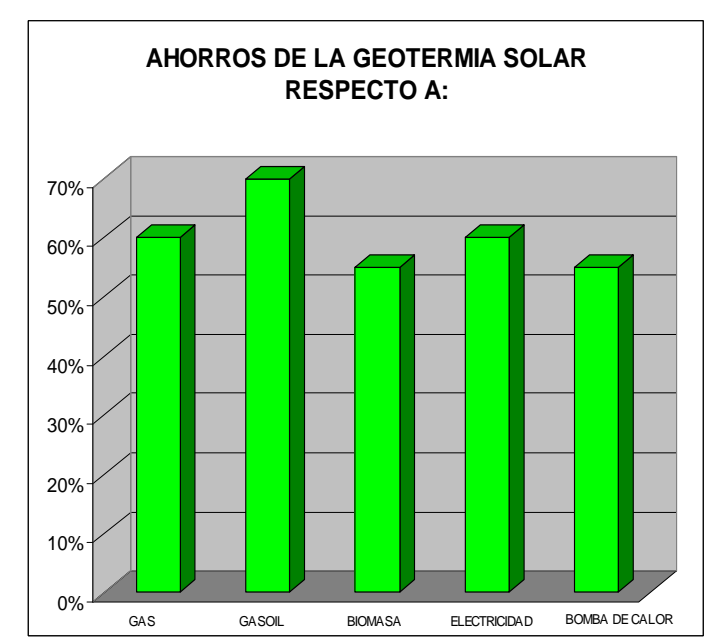

Figure 5 :Expected Energy saving

- Fast investment recovery estimated between 5 and 10 years.

- Passive installation (zero energy) ensured with the solar photovoltaic power covering the GHP needs.

- Decrease of the CO2 emissions because conventional combustibles are avoided (see figure 4).

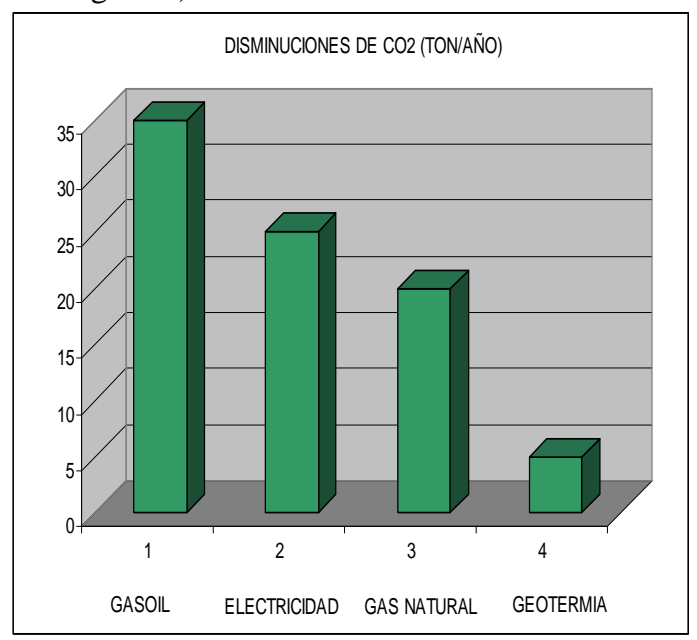

Figura 6 : Expected decrease of CO2 emisions compared with other habitual combustible in Tons per years.

- Decrease of the noise contamination level because no external condensed unit is need.

Bibliography:

1. - CLAESSON, J. \& ESKILSON, P. (1988).:

"Conductive Heat Extraction to a deep Borehole, Thermal Analysis and Dimensioning Rules." - Energy 13/6, S. 509-527 DIERSCH, H.-J.G. (2006).: “FEFLOW® 5.3 User's Manual." - WASY GmbH, Berlin, 200 S.

2.- GEHLIN, S. \& HELLSTRÖM, G (2000).: "Recent Status of In-Situ Thermal Response Tests for BTES Applications in Sweden."
Proc. Terrastock 2000, 159-164.

HELLSTRÖM, G. (1991).: "Ground Heat Storage, Thermal Analysis of Duct Storage Systems, I.” Theory. 262 p., LTH,

3.-HELLSTRÖM, G. \& SANNER, B. (1994).: Software fo $\mathrm{r}$ dimensioning of deep boreholes for heat extraction. - Proc. CALORSTOCK 94, S. 195-202, Espoo/Helsinki.

NORDELL, B. (1991).: "Cost effective design of borehole heat stores." - Proc. 5th int. Conf. Energy Storage THERMASTOCK 91, S. 3.1.13.1.7, NOVEM, Utrecht

4.- SANNER, B. (1999).: Kann man Erdwärmesonden mit Hilfe von spezifischen Entzugsleistungen auslegen? - Geothermische Energie 26-27/99, S. 1-3, Geeste (auch unter:http://www.geothermie.de/oberflaechenna he/erdwaermesonde/kann_man_erdwaermesond en_mit_hilf.htm

5.- SANNER, B. et al (2005).: “Thermal Response Test - current status and world-wide application." Proc. WGC 2005 Antalya, paper \#1436, 1-9.

6.-SANNER, B., MANDS, E., SAUER, M., SEIDINGER, W. (2002).: Das Low Energy Office der Deutschen Flugsicherung in Langen mit geothermischer Wärme/Kälte-Speicherung http://www.ubeg.de/Downloads/LeoDFSGerm.p df

7.- SAUER, M., MANDS, E., SANNER, B. \& GRUNDMANN，E. (2007).: "Wirtschaftliche Aspekte beim Einsatz von GeothermalResponse-Tests" , Tagungsband Geothermiekongress 2007 Bochum, Paper Nr. 124 